\title{
The local church as a non-governmental organisation in the fight against poverty: A historical overview of Bethulie 1933-1935
}

\author{
Author: \\ Johan van der Merwe ${ }^{1}$ \\ Affiliation: \\ ${ }^{1}$ Department of Church \\ History and Church Polity, \\ Faculty of Theology, \\ University of Pretoria, \\ South Africa \\ Note: \\ This article was initially a \\ presentation to the Poverty \\ Symposium 2013, directed \\ by Prof. Dr Johann-Albrecht \\ Meylahn, Department of \\ Practical Theology, Faculty \\ of Theology, University of \\ Pretoria, Pretoria, \\ South Africa.
}

Correspondence to:

Johan van der Merwe

Email:

johan.vdmerwe@up.ac.za

Postal address:

Private Bag X20, Hatfield

0028, Pretoria, South Africa

\section{Dates:}

Received: 27 Jan. 2014

Accepted: 26 July 2014

Published: 20 Nov. 2014

How to cite this article: Van der Merwe, J., 2014,

'The local church as a nongovernmental organisation in the fight against poverty A historical overview of Bethulie 1933-1935, HTS Teologiese Studies/ Theological Studies 70(1), Art. \#2617, 7 pages. http:// dx.doi.org/10.4102/hts. v70i1.2617

\section{Copyright:}

(C) 2014. The Authors. Licensee: AOSIS OpenJournals. This work is licensed under the Creative Commons Attribution License.

\section{Read online:}

Poverty is one of the greatest threats to society. In South Africa it is also one of the biggest challenges. This article starts with the challenges put to society by Mr Trevor Manuel at the Carnegie 3 conference. It then explores the possibility of if and how the church can act as a non-governmental organisation in the fight against poverty. A historical overview of the actions of Rev. E.P. Groenewald, during the drought of 1933-1934 in the Dutch Reformed Church Bethulie, serves as a case study of how the church can make a difference. It, however, also illustrates the many pitfalls on this challenging road. The article comes to the conclusion that the main challenge of the church in the fight against poverty is to act as a non-governmental organisation, which transforms values and assists society with good organisation and administration.

According to Ghandi (n.d) poverty is the worst kind of violence ('Poverty is the worst form of violence'.) This remark underlines the importance but also the challenges that poverty poses to every society. In South Africa nearly $50 \%$ of the South African population is living under the poverty line, according to the latest statistics of the World Bank (The World Bank 2013). This is one of the important reasons why the whole problem of poverty in South Africa cannot be ignored. This was confirmed by Trevor Manuel in his speech at the opening of Carnegie 3, on 03 September 2012 (Manuel 2012). This was a conference organised by the University of Cape Town in order to address the challenges of poverty in South Africa. In his opening address, Manuel (2012) explained:

As many of you are probably aware, the National Planning Commission identified poverty and inequality as the two biggest challenges facing us as this time. We still have a great deal of work to do to ensure that these two scourges are relegated to history.

The purpose of the conference was to move towards new ways of considering poverty and inequality, focusing less on describing the problems, and more on practical strategies to overcome them.' Manuel further stated that it required 'shifts in thinking, which the conference hopes to stimulate by combining a focus on academic and applied research with a set of demonstrations from the NGO, Business and Trade Union world' (C3 2013). Manuel also referred to this important issue when he asked if government was alone responsible for tackling the problem. He then said:

Whilst government should never be allowed to devolve its responsibility, the process is actually a bit more complex. The Commission is of the view that transformation occurs when a number of agencies interact. The first, and perhaps the most important of these is an active citizenry - a nation whose conscience is vested in the ordinary women and men who comprise and who act in their own and in the national interest - they cannot outsource this responsibility to government. The second agency is leadership focused, determined and manifest. When we speak of leadership, we counter the notion of the 'big man'. Our model of leadership is one that involves tens of thousands of active citizens who take initiative, in the common interest. The third agency is an effective government. This needs to be a clear objective at local, provincial and national levels. An effective government is responsive to the needs of its people, in its listening, policy priorities and allocation of resources. Without the close interaction of these three agencies, no transformation is possible. (Manuel 2012)

Although the church is not named specifically above as one of the organisations, the challenge to act concerning poverty is fundamentally part of the churches' calling as is being stated in the Belhar Confession part 4:

We believe that God has revealed himself as the one who wishes to bring about justice and true peace among men; that in a world full of injustice and enmity he is in a special way the God of the destitute, the poor and the wronged and that he calls his church to follow him in this; that he brings justice to the oppressed and gives bread to the hungry ... (Uniting Reformed Churches in Southern Africa [URCSA] 2013)

If Belhar is taken seriously it makes the church a very important role player in the struggle against poverty. It will also not be the first time that the church in South Africa is being challenged by 
poverty. It played a major role in the late 1920s and early 1930s when the poor white problem prevailed. The question may be asked, in the context of studying the 'poor white problem' which recalls the apartheid ghost from the past, can this problem contribute anything in addressing the current problem of poverty? This question was already answered by the previous State President of South Africa, Mr Nelson Mandela, in 1994 when he addressed the General synod of the Dutch Reformed Church in Pretoria. In his message to the synod, Mandela stated the importance of the churches in South Africa sending a clear message to society on economical justice. He also mentioned the special calling of the church concerning the poor and oppressed and specifically referred to the role which the Dutch Reformed Church played in the early 1930s. He explained this as follows:

In this regard there is the example of the role which the Dutch Reformed Church played with its aid schemes to Afrikaners who suffered under the drought of 1932 and the Great depression of 1932-1934. Unfortunately this educational aid schemes and health care programmes were aimed at white Afrikaners only. The church must broaden its vision to include South Africans of all races. (Nederduitse Gereformeerde Kerk 1994:536) ${ }^{1}$

Thabo Mbeki confirmed this point of view in 1999 in his explanation that there is much to be learnt from the way in which white Afrikaner leaders addressed the issue of poverty during the poor white problem in the 1930s. Me Qedani Mahlangu, chairperson of the Parliamentary committee for economics, echoed his sentiments in her speech to SABEK in 2003, saying that the Peoples congresses of the 1930s, which was organised by the church and the forthcoming state church aid schemes, are examples of which to take note (Du Toit 2003:1). The purpose of this paper is to revisit Bethulie in the Free State, one of the provinces of South Africa, as a case study where church and government became partners in addressing the challenge of poverty in a specific context in the early 1930s. Although the Dutch Reformed Church was a church for white Afrikaans speaking people at that time, ${ }^{2}$ and it addressed only white poverty, I agree with Mbeki that we must learn from the past in order to move forward in our current situation. Therefore, I will, before giving an overview of what happened in Bethulie, firstly define what I understand as a non-governmental organisation (NGO) and what I mean by the local church. Secondly I will give an overview of poverty in South Africa in general during the early 1930s. I will then discuss what happened in Bethulie before concluding that the local church, under certain conditions, can act as an NGO to address the challenges of poverty in society.

\section{Non-governmental organisations and the local church Non-governmental organisations}

Non-governmental organisations (NGOs), also known as civil society organisations (CSOs), are not a new

\section{My translation.}

2.The Dutch Reformed Church decided at its General Synod of 1986 that the church's doors and membership are open to members of all races in the country. development. They have existed for hundreds of years. Since the mid-19th century they have been increasing in numbers and gained international recognition, particularly amongst intergovernmental organisations (IGOs). NGOs were accepted and consulted by the League of Nations and were often permitted to participate in the League's meetings and committees. This recognition resulted in NGOs being included in the UN Charter, under Article 71 of Chapter 10, when the United Nations was created in 1945 (United Nations 2013). This inclusion prepared the way for NGOs to play a major part in the struggle against all kinds of injustice in society, poverty being one of them.

What then is meant by the term non-governmental organisation? The World Bank defines non-governmental organisations (NGO) as 'private organizations that pursue activities to relieve suffering, promote the interests of the poor, protect the environment, provide basic social services, or undertake community development' (Duke University Libraries 2013). This means that an NGO can be described as a non-profit voluntary citizens group which is organised on a local, national or international level. It is task-orientated and driven by people with a common interest. NGOs, therefore, perform a wide variety of services and humanitarian functions. It also brings citizen concerns to governments, advocates and monitors policies and encourages political participation through the provision of information. Some NGOs are organised around specific issues, such as human rights, environment and health. They can also provide analysis and expertise, serve as early warning mechanisms and they can help to monitor and implement international agreements (NGO Global Network n.d.). It is clear from this definition that an NGO can be an important tool for a local community in the struggle against poverty. It can also be the ideal vehicle for the church in the struggle against poverty if we understand the concept of the local church correctly.

\section{The local church}

What do I mean by local church? Many people understand the term the church or the local church as referring to a place or a building. The word 'church' in the New Testament comes from the Greek word ekklesia which is formed form two Greek words meaning an 'assembly' and 'to call out' or 'called ones' (Heyns 1981:359). This clearly indicates that 'church' in the New Testament does not mean a building or a place but rather a body of believers who have been called by God to live as his people (Eph 1:22-23). It all began on the Day of Pentecost, as described in Acts 2. All believers are members of this universal church which began through the word of the Holy Spirit (1 Cor 12:13) (Fairchild 2013).

Barth (1949:141) defines the church further by saying: 'Ekklesia certainly means congregation'. He then describes a congregation as the: '[C]oming together of those who belong to Jesus Christ through the Holy Spirit' (Barth 1949:141). This definition of Barth's means the church is also a local assembly of believers or a congregation that comes together for worship, fellowship, teaching, prayer and encouragement in 
the faith (Heb 10:25). It is in the congregation where believers are able to live in relationship with other believers (Fairchild 2013). The calling of this local church is best defined by the founder of the 'home church' movement in England, Canon Ernest Southcott:

The holiest moment of the church service is the moment when God's people-strengthened by preaching and sacrament-go out of the church door into the world to be the church. We don't go to church; we are the church. (Fairchild 2013)

The church is therefore not a place, a building or a location. It is God's people who believe in Jesus Christ and minister to the world. This makes the church important as one of the main instruments through which God carries out his purpose on earth. It is the body of Christ - his heart, mouth, hands and feet - through which he reaches out to the world (Fairchild 2013). This calling means that the local church has a specific calling with regard to the struggle against poverty in the local community. It is fundamental to who the church really is. As I stated in my introduction, this is confirmed by one of the newest confessions of faith in the church, namely the Confession of Belhar part 4:

We believe that God has revealed himself as the one who wishes to bring about justice and true peace among men; that in a world full of injustice and enmity he is in a special way the God of the destitute, the poor and the wronged and that he calls his church to follow him in this; that he brings justice to the oppressed and gives bread to the hungry ... (URCSA 2013; see also Botha \& Naude 2011:22)

If we define an NGO as a 'voluntary citizens' group' which can be organised on a local level to uplift the community and we state that the local church is a group of people with a specific calling in this world, it is not difficult to understand why the two can be aligned to enable the church to indeed function as an NGO in the struggle against poverty. The common factors are the local level and the group of people. The difference is found in the motivation of the group of people and the vision of the organisation. That is why the newly elected pope, Pope Francis, warned in his first Sistine Chapel Mass, on his first day as church leader ${ }^{3}$, that:

If we do not confess to Christ, what would we be? We would end up a compassionate NGO. What would happen would be like when children make sand castles and then it all falls down? (British Broadcasting Corporation [BBC] 2013)

With this remark the pope clearly stated that although the church must be committed to social upliftment, the church's motivation is not found in human suffering alone, but rather in the heart of God who makes himself present in this world through the deeds of His children. Karl Barth dentified this action of God as the missio Dei (Hancke 2006:38). By this he meant that the church's reaching out to the world in its suffering is not, in the first place, an action of the church but an attribute of the sovereign God who uses His church as an instrument in the world. This means that a local church, although acting as an NGO, can never just have a program for the struggle against poverty (Hancke 2006:38). It must always be imbedded in the mission Dei. In the words of Moltmann (1993:10), ' $[m]$ ission does not come from the church; it is from mission and in the light of mission that the church has to be understood'. He explains the importance of this concept further, ' $[m]$ ission embraces all activities that serve to liberate man from slavery in the presence of the coming God, slavery which extends from economic necessity to Godforsakeness' (Moltmann 1993:10). The case study of Bethulie in the early 1930s will help us to understand how problematic this can be at grass roots level.

\section{The broader context of South Africa: $1929-1937$ The poor White problem}

In order to understand what happened in Bethulie, it is important to look at the bigger picture of what happened worldwide, but especially in South Africa first. October 1929 will always be remembered for the Wall Street stock market crash in New York in the United States of America. This event signalled the beginning of the 10 year long Great Depression that affected all western industrialised countries (Giliomee 2003:356). South Africa, with its rich gold and diamond deposits and growing mine industry, was not spared. This becomes clear from a note by General Jan Smuts ${ }^{4}$ stating:

There has never been such a test to our economic civilisation, and it is still a question whether we can pull through without a serious challenge to our spiritual heritage. (Giliomee 2003:356)

Although the economic crisis affected the whole population of South Africa, the Dutch Reformed Church in Bethulie, which is the subject of this case study, focused primarily on the needs of its own members. This also happened in the rest of the church and is to my mind one of the biggest shortfalls of what was implemented. It does not, however, remove the fact that much can be learnt from the church's handling of the struggle against poverty.

The economic crisis in South Africa was worsened by a lengthy drought. By 1933 22\% of the white and non-white male population in South Africa were without work, the sheep population decreased by 15 million, the price of maize was halved and many farmers were bankrupted. This led to a mass urbanisation of Afrikaners: $29 \%$ in 1910 compared to 50\% in 1936 (Giliomee 2003:356). Herman Giliomee (2003) explains in his book The Afrikaners: Biography of a people:

The so-called poor white problem became the most pressing social issue in Afrikaner politics early in the 20th century and retained that status until the early 1940s, when the search for a new approach to the racial problem replaced it. (p. 357)

Vosloo (2011) is correct when he states that the new industrial situation in South Africa led to a growing concern, in the church, for the poor. He explains this as follows:

After the first decade of the 20th century the church's response to white poverty became more deliberate and organised in the wake of growing urbanisation. In 1915 the Cape Synod called into being a synodical commission for Inwendige Zending ('Internal Mission') which in 1919 became Die Algemene Armesorg-kommissie and Rev. A.D. Luckhoff was appointed as the organising secretary in 1916. (p. 3)

4.General Jan Smuts was Prime Minister of the Union of South Africa from 1919 to 1924 
The Dutch Reformed Church's reaction to the poor white problem is reflected in important conferences which were held to address the problem (Nederduitse Gereformeerde Kerk 1994). ${ }^{5}$

\section{The Carnegie report}

A direct result of the conferences in Cradock, Stellenbosch and Bloemfontein was the Carnegie enquiry which resulted in the Carnegie report of 1932. After the chairman of the Carnegie Corporation visited South Africa in 1927, the Carnegie Corporation decided to fund scientific research into the poor white problem (Bottomley 2012:110). Vosloo (2011) describes the beginning of the Carnegie enquiry when he writes:
A Management Council was established in 1928, which included representatives of the Dutch Reformed Church, the Council for Research Grants and additional members. The Dutch Reformed Church also paid the salary of Dr. JR Albertyn during the time of his active participation in the process as representative of the Dutch Reformed Church and report writer. The Universities of Stellenbosch and Cape Town, as well as several other government and non-governmental organizations, provided the necessary funding that enabled their members to participate in the inquiry as well. (p. 4)

The commission published its findings in 1932 in five volumes. What are important for the scope of this article were the comments made by the commission about the involvement of the state, voluntary organisations and the church. The Carnegie report made it clear that both economic change and psychological change, within the poor persons themselves, were needed to facilitate sustainable change (Grosskopf 1932:xxix). What happened in Bethulie was a practical result of what was stated in the report.

\section{Bethulie}

Bethulie is a small town in the southern part of the Free State, one of the provinces of South Africa. It was founded in May 1828 , as a Mission station of the London Missionary Society, with the sole purpose of ministering to the San people who lived in the area. Dippenaar is correct in her statement that cattle theft and conflict between the different race groups formed part of the tragic history of the region which made mission work in the area extremely difficult (Dippenaar 2011:32). In 1834 the Rev. J.P. Pellisier, from the French Missionary society, took over the school and changed the mission post's name to Verhuepolis. The French made a huge success with mission work under the Betsjoeanas and soon changed the name of the mission station again, to Bethulie, in 1835 (Dippenaar 2011:32). By 1839 there were 14 converts at the mission station. Conflict between the Griekwas ${ }^{6}$ and the missionaries, as well as a measles epidemic, hampered the work of the missionaries. With more white farmers moving into the area, the mission station was closed in 1863 and the town of Heidelberg was proclamated (Dippenaar 2011:32).

5.The conferences took place in Cradock 1916, Stellenbosch 1922 and Bloemfontein 1923.

6.The Griekwas were a local tribe living in the south-eastern Free State.
In 1872 the name of the town changed again when the 'Volksraad' changed it to Bethulie.

It was, however, during the Anglo Boer war (1899-1902) that Bethulie became important when the third largest concentration camp ${ }^{7}$ was established at the outskirts of the town. During the war, an estimated 28000 women and children died in the concentration camps (Giliomee \& Mbenga 2007:220). After the Anglo Boer war the depression and the drought of 1933 led to very difficult circumstances in what was mainly a farming community (Dippenaar 2011:34). Many farmers lost all their cattle in this drought. Others could not sell their cattle, wool and maize resulting from bad economic circumstances (Meiring 1933:289). Bethulie did not escape this escalating crisis.

\section{The arrival of E.P. Groenewald ${ }^{8}$ in Bethulie: October 1932}

Groenewald wrote about the circumstances at the time of his calling to Bethulie:

I came back to my parent's home in George in 1932 after I graduated in Amsterdam. It was a very difficult year. The economic depression caused major unemployment; the country was in political turmoil due to the coalition between Hertzog and Smuts while tension in the church was still high due to the Du Plessis case. (Groenewald 1985:1)

Groenewald was also ticketed as a supporter of Du Plessis because he thanked Du Plessis, who was his first Professor in New Testament, in his thesis (Dippenaar 2011:43). In these difficult times, Groenewald received a calling to Bethulie, a town about which he knew nothing. He accepted the call and arrived in Springfontein by train on 07 October 1932 where he was met by the church council of Bethulie (Groenewald 1985:2). He was confirmed as minister of Bethulie on 08 October 1932 and delivered his inauguration message on 09 October 1932. He described Bethulie as a small town without electricity and with no tarred roads (Groenewald 1985:4). Groenewald started his ministry here with pastoral visits to all the members of the congregation (Groenewald 1985:6). Regarding this he wrote, ' $[i] \mathrm{t}$ took me a few weeks to finish all the house visits in the town. The overwhelming impression that I got was that of extreme poverty' (Groenewald 1985:8).

\section{Poverty in Bethulie}

Groenewald (1985:7) wrote in his report that ' $[t]$ he extent of poverty and unemployment was alarming. Later I established that there were more than 70 families who were without any source of income'. The common problem was the drought. There had been little rainfall the previous summer and the winter of 1932 was also without rain. By February 1933 the situation became critical and farmers were suffering and moving away from their farms. It was, however, not only on the farms that people were suffering. Families of railway

7.The concentration camps were camps in which women and children were kept during the second South African war which took place from 1899 to 1902.

8.E.P. Groenewald later became professor in New Testament studies at the Faculty of Theology, University of Pretoria. He retired as Dean of the Faculty of Theology section B. 
workers in Bethulie were also suffering. Groenewald (1985) explained:

Once again I was confronted with severe poverty in the cottages where the railway workers and their families lived. Large families had to live on a small income and could not make ends meet. (p. 8)

In the district of Bossiespruit he encountered a little farm school where the children of the local farmers attended school. There was no transport or money for transport to attend the school in town. Their self-appointed teacher was a boy who had just finished school himself. As the drought continued, the misery grew and something drastic was required. On 06 April 1933 Groenewald met with the local magistrate to discuss the problem and ask for help (Groenewald 1985:10). By mid-1933 Groenewald once again mentioned the drought and unemployment as two critical problems in Bethulie. The drought continued through 1933 and the situation became desperate. Farmers moved away from their farms to look for food for their surviving cattle. Groenewald (1985) described the situation as follows:

More than once I had to stop my car so that herds of thin and tepid Springbok could cross the road. They were so weak that they could not get up when they fell. (p. 12)

The westerly winds were dry and led to huge dust storms. On 11 October 1933 the dust became so excessive that children were sent home from school. Boreholes began to dry up and by 08 November 1933 the dam that provided the town with water was also dry.

Groenewald tried to support members of his congregation through pastoral visits and preaching, but soon realised that it was not enough. Something else was urgently needed. The turning point came when he visited a farm where the farmer has tied the carcass of a dead calf to the gate with the heading 'Does God not see?' Groenewald (1985:15) wrote: 'The sun did not forget us. It was if the sun even scorched our prayers. The continuing westerly wind was stealing people's faith.' The drought and the depression took its toll and challenged the local church into action.

\section{The local church acts on poverty}

Groenewald's discussions with the magistrate continued and he succeeded in finding employment for a few people. As the drought continued, unemployment became more severe. An increasing number of people came to the church to borrow money for food. On 29 August 1933 a meeting, organised by the church, took place where the situation was discussed and a committee was appointed, which decided to take the matter to the government. On 27 September, the local member for parliament, Mr Clasie Havenga addressed a meeting in town which led to a visit from Mr G Otto, inspector of labour from Bloemfontein (Groenewald 1985:18). Plans to find work for the people of the town were discussed. It was decided to enlarge the dam of the town and to rebuild the road to Bethulie. The gravel needed for the road required a quarry which was dug on the outskirts of the town. This was the beginning of the so-called church-state aid scheme in Bethulie. The government provided the funding whilst the local church performed the organisation and administration at ground level. This scheme was the brainchild of Rev. P.J. Pienaar, the secretary for care of the poor and needy of the Dutch Reformed Church in the Free State. Oosthuizen (2009) describes the scheme by explaining:

Church and state were the two pillars on which the rebuilding of society rested. The state was responsible for the economic reconstruction and the church for the spiritual reconstruction. Where the two overlapped, partnerships were formed. (p. 97)

According to the scheme the whole province was divided into different areas. Local churches were required to appoint committees, with the local magistrate as a permanent member, and the minister of the congregation as chair. The government would provide funding and work and the church would provide administration and organisation. Groenewald (1985) elaborates on the scheme:

Initially I was quite happy to provide somebody with work and to pay him for the work with money coming from government. As time passed, it became a thankless job. There were usually many more unemployed people than jobs provided. Men that did not get employed started saying that the minister is against them and that he has no heart for the hungry children in their homes. (p. 19)

Groenewald commented further, that the scheme prevented rather than promoted pastoral and spiritual work.

In March 1934 he discussed the matter with one of the organisers of the scheme, Rev. E. van der Horst, but nothing changed. Later in 1934 many of the labourers left their jobs, resulting from low salaries and bad working conditions, and came to the local church to ask the minister to lodge complaints on their behalf (Groenewald 1985:19). When the minister refused to do this, he was accused of apathy. Groenewald explained that ' $[t]$ he scheme made the minister of the local church a civil servant' (Groenewald 1985:20). On 01 September 1934, after a lengthy discussion, the church council of Bethulie decided to withdraw from the scheme. The actual withdrawal took several months (Nederduitse Gereformeerde Kerk 1994). During that time Groenewald continued to deal with labour unrest. On 01 November 1934 he had to request workers from elsewhere, the result of which contributed to the discontent of the inhabitants of Bethulie. At a meeting on 16 November 1934, the displeased workers had an opportunity to discuss their complaints with the committee and most of their problems were resolved. On 25 January 1935, Groenewald handed the files of the committee to Mr Jardine, the postmaster of the town, who took over as chairperson of the committee. Shortly thereafter the whole scheme ended. Groenewald commented that ' $[i] \mathrm{t}$ was help in a time of need, but not caring for the poor as the church should do it' (Groenewald 1985:20). Although the local church in Bethulie took up the challenge of addressing poverty and unemployment, the partnership with government proved problematic. 


\section{Conclusion}

Was the church-state aid scheme in Bethulie successful or not? How can it help us on the way forward when thinking about the local church as an NGO in the struggle against poverty? The answer to the first question is yes and no. It is possible to answer yes because church and state joined hands and partnered together to reach out to the poor and the unemployed. The state provided what the church could not: money and jobs and the church provided what the state could not: sound organisation and administration. The church was the face to the community, and the organisation which addressed the problem of unemployment and poverty. In doing so it acted in the same way as an NGO. The unemployed found jobs, and money was available to assist the very poor. From that perspective, it was successful. Although the partnership made a difference in the lives of people in the local community, the church was bound by the source of its monetary support, in this case the state. This intervention compromised the missio Dei of the church and made the church in Bethulie, in the words of Pope Francis, just a compassionate NGO. Groenewald describes it best in his own words, '[i]t was help in a time of need, but not caring for the poor as the church should do it' (Groenewald 1985:20). What was the problem in Bethulie? The local church became an extension of government. As Groenewald himself complained, 'I became a kind of civil servant'. This interfered with his pastoral work and made him the scapegoat of discontented workers. The church-state aid scheme did not fit into the missio Dei as described earlier in this paper. Although partnerships are possible, it should be very clear from the outset that the contribution of whoever the partner of a local church may be, that it may not compromise the calling and the message of the church.

On the other hand, Danaldi Musa (2009) directs us in the right direction by saying:

This lack of involvement of the local church in the development process has made the church not to be truly the light and salt of the community in which it is situated. It has also made the church not to have a positive influence on the community. It also makes the church's evangelistic efforts ineffective as the church tends to overlook many needs in the community. The lack of involvement also makes the church to be more inward looking instead of being outward looking, reaching out to the people around and beyond. The local church should see development programmes as part and parcel of their ministry. As the local church is part of the community, it should embark on community mobilisation programmes aimed at enabling people to identify, analyse, plan and take action to solve their problems so that people can live fulfilled lives as intended by God. If local churches are involved in this way, then the role of church development departments would then need to change from direct involvement with communities to building the capacity of local churches to carry out holistic development. (p. 1)

Musa motivates his point of view correctly by emphasising that the local church is the best placed to minister to the local community both physically and spiritually. He continues by identifying two main roles that the church should play in the local community. These are transformation of values and community organising. He states, '[o]ne of the first programmes that churches should embark upon is moral recovery through intentional values transformation based on the Bible the infallible word of God' (Musa 2009:3). He further explains that:

The values that must be in place to enhance poverty alleviation and community transformation would include the following: Love for one another, Honesty and sincerity; Community spirit; Accountability; Decision making by consensus; Hard work; Discipline; People's creativity; Indigenous/appropriate technologies and justice. (p. 6)

He defines the second role as follows:

Community organising is the process of getting people to identify and solve their community problems through collective actions that will neutralise or eliminate the immediate or radical causes of the problem and constraints to a holistic quality of life of the community. They go deeper to find out the root causes of their poverty and find possible solutions to them. (Musa 2009:6)

In conclusion, can a local church act as an NGO or a primary development agent? I do not think a local church can; I think a local church has to! There is no choice. History provides the example of how it was accomplished in the past. By not repeating the same mistakes, the local church acting within the missio Dei, has a huge contribution to make in the struggle against poverty.

\section{Acknowledgements Competing interests}

The author declares that he has no financial or personal relationship(s) that may have inappropriately influenced him in writing this article.

\section{References}

Barth, K., 1949, Dogmatics in outline, transl. G.T. Thompson, London, SCM Press. Botha, J. \& Naude, P., 2011, Good news to confess, Mega Digital, Cape Town. Bottomley, E., 2012, Poor white, Tafelberg, Cape Town.

C3, Towards Carnegie III, 2013, Overcoming poverty and inequality in South-Africa, viewed 13 February 2013, from http://www.carnegie3.org.za/

Dippenaar, S., 2011, 'Dr EP Groenwald en die armblankevraagstuk', ongepubliseerde MDiv mini-verhandeling, Departement Kerkgeskiedenis en Kerkreg, Universiteit van Pretoria.

Duke University Libraries, 2013, World Bank and NGO's, viewed 20 May 2013, from http://guides.library.duke.edu/ngo_guide

Du Toit, Z.B., 2003, 'Perspektief-wit armoede 1933, swart armoede 2003 ... daar is 'n groot verskil', Rapport, 26 Oktober, 2003, bl. 1.

Fairchild, M., 2013, 'What is the Church? The Church - place, person or thing?', in About Religion, viewed 20 May 2013, from http://christianity.about.com/od/ churchandcommunity/a/thechurch.htm

Ghandi, n.d., 'Poverty is the worst form of violence...Ghandi', in A reason to write, viewed 10 February 2013, from http://areason2write.wordpress. com/2009/08/15/poverty-is-the-worst-form-of-violence-ghandi/

Giliomee, H., 2003, The Afrikaners: Biography of a people, Tafelberg, Cape Town.

Giliomee, H. \& Mbenga, B., 2007, New history of South Africa, Tafelberg, Cape Town.

Groenewald, E.P., 1985, 'Werk en wedervarings op Bethulie: Oktober 1932 Januarie 1938', ongepubliseerde memoirs, private versameling, J.M. van der Merwe, Pretoria.

Grosskopf, J.F.W., 1932, Die armblanke-vraagstuk in Suid-Afrika: Verslag van die Carnegie-kommissie (Deel I). Ekonomieseverslag: Plattelandsverarming en Plaasverlating, Pro Ecclesia-Drukkery, Stellenbosch.

Hancke, F., 2006, Ons is die plan, Swift Print, Kimberly. 
Heyns, J.A., 1981, Dogmatiek, NG Kerkboekhandel Transvaal, Goodwood.

Manuel, T., 2012, 'Address to the opening session of Strategies to overcome poverty and inequality - Towards Carnegie III', Carnegie 3, University of Cape Town, 03 September 2012, viewed 10 February 2013, from http://www.gov.za/speeches/ view.php?sid=30350

Meiring, P.G.J., 1933, 'Die ontsettende droogte', Die Kerkbode, 15 Februarie, 1933, bl .15.

Moltmann, J., 1993, The Church in the power of the Spirit, SCM Press, London.

Musa, D., 2009, The local church as primary development agent, viewed 21 May 2013, from http://www.ccjp-lilongwe.org/downloads/Role_of_Local_Church.pdf

Nederduitse Gereformeerde Kerk, 1934, Notule van die Kerkraad van die NGK Bethulie 1 September, Kerkargief.

Nederduitse Gereformeerde Kerk, 1994, Handelinge van die Negende Algemene Sinode van die NGK, Kerkargief.

NGO Global Network, n.d., Definition of NGOs, viewed 26 May 2013, from http:// www.ngo.org/ngoinfo/define.html
Nieuwoudt, T., 2002, '1915. 'n Reddingsaksie vir armoede', in NG Kerk 350 jaar Gereformeerd, Lux Verbi, Wellington.

Oosthuizen, A., 2009, 'Helpende hande: Kerk en staat in vennootskap - of nie?' , in Gebroke land-armoede in die Afrikaanse gesin sedert 1902, Kraal uitgewers, Brandfort.

'Pope Francis warns Church could become "compassionate NGO"', 2013, British Broadcasting Corporation $(B B C)$, viewed 25 May 2013, from http://www.bbc com/news/world-europe-21793224

The World Bank 2013, Poverty and equity, viewed 10 February 2013, from http:// povertydata.worldbank.org/poverty/country/ZAF

United Nations, 2013, 'NGO Branch, Department of Economic and Social Affairs', viewed 27 May 2013, from http://www.csonet.org.

Uniting Reformed Churches in Southern Africa (URCSA), 2013, Belhar Confession and accompanying letter, viewed 15 March 2013, from http://www.urcsa.org.za/ documents/The\%20Belhar\%20Confession.pdf

Vosloo, R.R., 2011, 'The Dutch Reformed Church and the poor white problem in the wake of the first Carnegie Report (1932): Some church-historical and theological wake of the first Carnegie Report (1932): Some church-his.
observations', Studia Historiae Ecclesiasticae 37(2), 67-85. 